\title{
SCHOOL HEADS' LEADERSHIP PRACTICES AND TEACHERS' PERCEPTION ON SCHOOLS READINESS TO DISTANCE EDUCATION
}

\author{
Glenford C. Franca ${ }^{1}$, Ma. Melanie N. Edig' ${ }^{2}$, Ronald S. Decano ${ }^{3}$ \\ ${ }^{1}$ Graduate Student, Doctor of Philosophy in Educational Management, Davao del Norte State College \\ and Faculty, Southern Philippines Agri-business And Marine and Aquatic School of Technology \\ ${ }^{2}$ Faculty, Institute of Advanced Studies, Davao del Norte State College \\ ${ }^{3}$ Dean, Institute of Advanced Studies, Davao del Norte State College
}

Article DOI: https://doi.org/10.36713/epra9409

DOI No: 10.36713/epra9409

\begin{abstract}
Amidst the threat of COVID-19, schools are shifting from face-to-face classroom instruction to the distance learning education. This recent challenges heavily relies on the shoulders of school heads who are expected to lead. Though a lot of articles credited the school heads for their preparation to the distance education, very few supported this with research results. Will the data coincides with this notion? Thus, this study investigates the relationship between the school heads' leadership practices and schools' readiness to distance education. The study was conducted using descriptive - correlational method. A total of 14 school heads and 110 teachers were subjected to the study. Descriptive statistics was used to determine the respondents' leadership practices and schools' readiness to distance education. Correlation analysis was employed to test the degree of relationship between the variables. Results show that school heads have excellent leadership practices and the schools are remarkably ready for the distance education. The correlation analysis shows Modelling the Way significantly correlated to the dependent variable. Generally, low correlation among the variables is obtained. Multiple regression analysis reveals that - Modelling the Way, Enabling Others to Act, and Encouraging the Heart significantly influence schools' readiness to distance education.
\end{abstract}

KEYWORDS: School Heads' Leadership Practices, Teachers' Perception, Schools Readiness, Distance Education

\section{INTRODUCTION}

An infectious coronavirus disease, known as COVID-19, has easily spread around the globe tallying a number of positive cases in almost every region which prompted the World Health Organization to declare a pandemic on March 11, 2020. Since then, most countries strictly implemented community quarantines and imposed public health measures, including wearing face masks, hand hygiene, respiratory etiquette, and physical distancing (Miranda, 2020).

In the Philippines, amidst the threat of COVID-19, schools are shifting from face-to-face classroom instruction to the distance learning education, where teachers, students, and parents are trying to cope and adjust with (Lapada, 2020). The pivot to remote teaching and learning has necessitated new transformational learning for all stakeholders and strenuous adaptation effort, since many academic institutions lack the requisite digital infrastructure (Fernandez and Shaw, 2020). It is often said that during crises leaders emerge. Stepping up to lead during this unprecedented crisis can fulfill a fundamental craving for meaning and purpose (Sherratt and Payne, 2020). In the school context, the responses to the recent challenges heavily rely on school heads who are expected to lead. As Franca (2019) stressed, school administrators must motivate others as well as form teams and build relationships like responding to such crises. It is believed that as teachers grapple with teaching remotely while 
schools are closed, principals and school heads can support their staff, students, and school communities in critical ways (Gonser, 2020).

In spite of the abundance of literatures on school heads' leadership practices, there seems to be no recent studies exploring leadership practices in relation to the school's readiness to engage in the distance learning approach due to COVID-19 pandemic. Thus, this study is proposed.

It can be perceived that the leadership practices of challenging the process, inspiring a shared vision, enabling others to act, modeling the way and encouraging the heart school managers could assess their leadership strengths and weaknesses and improve their leadership performance. It also provided a basis for the selection of materials for enhancing in-service components in school leadership for school districts and for pre-service courses in educational leadership for universities charged with training principals. Thus, the results of this study will contribute valuable insights on how to implement this kind of impetus to the effect of distant learning activities during pandemic. These are helpful in planning for the enhancement of the teaching - learning process of the school learners.

The researcher believes that the study will benefit the following:

The Education Sector - The result of the study would serve as a reference material for school heads and principals, researchers and other stakeholders in the education sector in matters related to leadership practices and the readiness of the school towards distance education during this time of pandemic.

Government Agencies and Other Organizations- The result of the study would serve these organizations in formulating efficient and effective leadership practices for public school heads, managers and teachers that would result to better school management. Moreover, policy makers can use the study to develop informed policies/decisions on how readiness to distance learning be implemented during the pandemic.

The School Heads and Teachers- The result of the study would increase their level of understanding with regard to handling their subordinates and co-workers in their respective workplaces or institutions. This would also tell what particular attitude or behavior needs to be enhanced and improved as manifested of being a leader.

Students- When work attitudes of teachers are disclosed through the result of this study, corrective measures, if necessary would be applied. In the end, the students would benefit from this study.

The Research Community- This study will further contribute to the knowledge concerning the factors that influence the leadership practices among the school managers and teachers. Findings may stimulate future research on the topic.

This study will focus on how the school heads leadership practice related to the school's readiness to distance education as perceived by the respective school teachers during the COVID-19 pandemic classes of SY 2020-2021 in public secondary schools of Malita, Davao Occidental.

The instruments to be used are limited only on the questionnaires freely downloaded from the internet's public domains. These are: Leadership Practices Inventory (LPI) by Kouzes and Posner (1993) and the schools' readiness to distance education as perceived by the school teachers formulated by Lapada (2020).

\section{Research Locale}

\section{METHODOLOGY}

The study will be conducted in the 13 public secondary schools in the municipality of Malita, Davao Occidental. The said secondary schools are Ernesto Lopez Sr. National High School, Demolok Valley National High School, Tomas Lim Alcordo National High School, Gaspar Danwata National School, Bolila National High School, B'laan National High School, Ticulon National High School, Clotildo Reyes Barrios Sr. National High School, Benjamin Velasco Bautista Sr. National High School, Mariano Peralta National High School, Fishing Village Comprehensive National High School, Lacaron National High School, and Tubalan Comprehensive National High School.

\section{Research Design}

The study will be quantitative in nature and will employ a descriptive correlational research design. This will involve the systematic investigation of the nature of relationships, or associations between and among dependent and independent variables It is most commonly used when seeking statistical relationships between two variables without manipulating the data themselves (Alexander, 2012).

The variables leadership practices of school heads and schools' readiness to distance learning as perceived by the teachers, will not be, in any way manipulated. The data will simply be subjected to observation and from the data, relationships of both independent and dependent variables will be checked, collated and interpreted to 
determine if there will be emerging trends and patterns. This statistical process will be done without treating or changing the data itself.

\section{Sampling Design and Techniques}

Total population sampling will be employed in identifying the respondents for the self-rating Leadership Practice Inventory (LPI) questionnaire. This is possible because there are only 13 number of secondary schools under study with a total of 14 school heads. To determine the sample size of teachers per school who will respond to the questionnaire on peer-rating Leadership Practice Inventory (LPI) questionaire, stratified random sampling technique will be applied to ensure proportional distribution of respondents and to avoid biases in the selection.

From the population of high school teachers, a sample size will be determined using the Slovin's formula. This will allow the researcher to sample the population with a desired degree of accuracy.

\section{Respondents of the Study}

The respondents to this study are the school heads and their respective teachers of public secondary schools of Malita, Davao Occidental for the School Year 2020-2021. The school heads and will respond to the self-rating Leadership Practice Inventory (LPI) questionnaire while the school teachers will assess the leadership practices of their school heads by answering the peer-rating Leadership Practice inventory (LPI). All of them will respond to the questionnaire on schools' readiness to distance education during the COVID-19 pandemic.

\section{Research Instruments}

Descriptive survey questionnaires will be utilized in this study which are freely obtained from the internet's public domains. The instrument for school heads leadership practices will be divided into two (2) parts. The first part will be for the demographic profile of the respondents and the second part is the Leadership Practice Inventory (LPI) questionnaire which will be based on the adopted Leadership Practice Inventory (LPI) by Kouzes \& Posner (1993) with reported internal reliability ranging from 0.80 to 0.91 Cronbach's alpha coefficients. The thirty (30) questions for the LPI contains the following indicators; a. Model the way - statements 1-6; b.Inspire a shared vision - statements 7-12; c. Challenge the process - statements 13-18; d. Enable others to act - statements 19-24; e. Encourage the heart -statements 25-30 of the questionnaire will be scaled from 1 to 5 where 5 - Almost always, 4 - Fairly often, 3 - Sometimes, 2 - Once in a while, and 1 - Rarely.

The schools' readiness to distance education as perceived by the school teachers will be based on the adapted questionnaire formulated by Lapada (2020). The ten (10) items in the questionnaire will be retained but the choices shall be modified to accommodate broader perceptions among the teacher-respondents. Originally, the questions are answerable only by "yes", "no", or "maybe". Modification will yield the adapted responses of 1 to 5 where 5 Strongly Agree, 4 - Agree, 3 - Neither Agree or Disagree, 2 - Disagree, and 1 - Strongly Disagree. The adapted questionnaire will be submitted to the adviser for comments and corrections. It will be subjected to validation by at least three (3) experts in research and education. Two (2) internal validators from the institution and one (1) external validator from other education agency will validate the questionnaire using the institution's validation sheet. This questionnaire considers the two domains - the teachers' readiness (items 1-5) and school preparedness (items 6-10).

\section{Data Analysis}

The data gathered will be tallied, tabulated, and prepared in a manner suitable for use in SPSS. The following statistical tools will then be employed to generate and interpret the results:

Percentage will be employed in analyzing the profile of the respondents in terms of age, gender, educational attainment, and years in service.

Mean will be employed to determine the level of Leadership Practice Inventory (LPI) among the secondary school heads, and the level of schools' readiness to distance education as perceived by the teachers. It will also be utilized to describe the profile of the respondents.

Spearman Correlation Analysis- This tool will be used to determine the relationship between the level of leadership practices among the secondary school heads, and the level of schools' readiness to distance education as perceived by the teachers.

The correlation coefficient (r) will be used to analyze relationship of two variables on the following basis (Higgins, 2005): 
Multiple Regression Analysis - This tool will be used to determine which among the domains of Leadership Practices significantly influence the schools' readiness to distance education.

\section{Results And Discussion}

This study, entitled "School Heads Leadership Practices and Secondary Schools' Readiness to Distance Education due to COVID-19 Pandemic was conducted to the high school institutions in the municipality of Malita, Davao Occidental. Out of 13 participating secondary schools, 6 are considered medium-size, 5 are considered small, only one school is considered large, and also one school is considered very large. In terms of School-Based Management (SBM) levelling, 6 schools were of level 3, 6 schools were of level 2, and 1 school is of level 1. This infers that this study is represented by respondents coming from different schools.

In general, the respondents rated the school heads with "excellent" leadership practices which means that they played a key role in setting direction of their schools and ensuring consistently good teaching and learning. All of the five (5) domains of leadership practices also obtained excellent ratings. The domain "Modeling the Way" obtained the highest mean rating of 4.952, followed by Inspiring a shared vision, Encouraging the heart, Enabling others to act, and Challenging the process with mean rating of 4.917, 4.917, 4.881, and 4.798, respectively.

The schools are remarkably ready to distance education as perceived by the secondary school teachers, obtaining a general mean of 4.724. Among the two domains considered, schools' preparedness obtained higher rating of 4.837 followed by 4.610 rating for teachers' readiness.

The Spearman correlation analysis reported two domains of leadership practices - Challenging the Process, and Inspiring a Shared Vision which obtained slight positive correlation to schools' readiness to distance education, while the other two domains - Enabling Others to Act and Modelling the Way exhibit moderate correlations. One domain - Encouraging the Heart obtained a negative low correlation to schools' readiness to distance education. Moreover, four of the five generated p-values in Table 7 are all greater than 0.05 level of significance which interpreted as "not significant". Only the Modelling the Way domain is significantly correlated to the schools' readiness to distance education. This obtained a p-value of 0.047 which is greater 0.05 level of significance. The overall p-value for leadership practices is also greater than 0.05 , which implies that we failed to reject our null hypothesis $\mathrm{H}_{01}$, and conclude that there is no significant relationship between Leadership Practices of the School Heads and Schools' Readiness to Distance Education.

Among the five domains considered in the leadership practices of the school heads, the Modelling the Way, Enabling Others to Act, and Encouraging the Heart significantly influence schools' readiness to distance education. It obtained a coefficient of $0.714,0.934$, and -0.877 , respectively. Hence, we reject the null hypothesis $\mathrm{H}_{02}$ and conclude that there is a domain of leadership practices of the school heads that significantly influence schools' readiness to distance education. The $\boldsymbol{r}^{2}=\mathbf{0 . 7 3 7}$, which reveals that $73.70 \%$ of the considered data fit the regression model.

\section{Conclusion}

Based on the findings, the following conclusions were formulated:

1. Most of the secondary schools in the municipality of Malita are considered medium size and small-size. There is only one large school and one very large school. In terms of School-Based Management (SBM) levelling, most of the schools are considered level 2 and level 3.

2. In general, the school heads have an "excellent" leadership practices which means that they played a key role in setting direction of their schools and ensuring consistently good teaching and learning.

3. The schools are remarkably ready to distance education as perceived by the secondary school teachers.

4. The Modelling the Way domain of Leadership Practices is significantly correlated to the schools' readiness to distance education. As the level of this domain increases, the readiness to distance education will significantly increase.

5. Readiness to distance education is significantly influence by the domains of leadership practices of the school heads: the Modelling the Way, Enabling Others to Act, and Encouraging the Heart. Manipulating these domains will significantly influence the level of readiness to distance education.

6. The $\boldsymbol{r}^{\mathbf{2}}=\mathbf{0 . 7 3 7}$, which reveals that $73.70 \%$ of the considered data fit the regression model. Hence, there are still other factors which contributed to schools' readiness to distance education that are not considered in this study. 


\section{Implications and Recommendations}

In the school context, it is generally agreed that responses to the recent challenges heavily relies on the shoulders of school heads who are expected to lead. Though a lot of opinions credited the school heads for their preparation to the distance education, very few supported this with research results. Will the data coincides with this notion? This study tried to substantiate this by examining the relationship of Leadership Practices domains to the schools' readiness to distance education. Yes, true enough, this study reveals that school heads are performing excellent leadership practices to prepare their teachers and schools to distance education in this time of pandemic. Thus, making this study worthwhile and relevant. With the results of this study, the following are recommended:

1. The respondents of this study is focused on the secondary schools of Malita only. It would be worthwhile to consider expanding the scope of the study with the inclusion of other secondary schools in the Province of Davao Occidental.

2. Though the school heads were rated "excellent" in their leadership practices by the teachers, yet, it would be better to continue supporting the leadership endeavours of the school heads by continuing trainings and education particularly in this changing times.

3. Though the schools are remarkably ready to distance education as perceived by the secondary school teachers, but until now, there is still no "perfect model" of instruction to this new normal. Hence, it is recommended that the schools will continue to explore efficient mode of delivery which will consider flexibility and suitability to all walks of learners.

4. The Modelling the Way domain of Leadership Practices is significantly correlated to the schools' readiness to distance education. Exploring this domain would be worthwhile particularly in this new normal.

5. Readiness to distance education is significantly influence by Modelling the Way, Enabling Others to Act, and Encouraging the Heart. Hence, strengthening these domains will significantly increase schools' readiness to distance education.

6. The study reveals that $73.70 \%$ of the considered data fit the regression model. Hence, exploring other factors which might contributed to schools' readiness to distance education is recommended.

\section{ACKNOWLEDGEMENT}

I, Glenford C. Franca, MAED, LPT would like to extend my heartfelt appreciation and gratitude to the following people who contributed immeasurably to the success of this piece of work. Dr. Ronald Decano, the Dean of the Graduate School of Davao del Norte State College for his encouragement to finish this research. My research adviser Dr. Ma. Erlinda Edig and The examiners panel who were shares their constructive comments and suggestions that helped me in improving this manuscript well. To Dr. Mark Van M. Buladaco, who was helping and finishing this paper for publication. In addition, I would also like to thank my wife and friends for being my inspiration and to their support. To my teachers respondents who contributed greatly to make this manuscript possible within a limited time frame. Finally, and most importantly, I would like to thank to our almighty God for the guidance and power 1 to achieve this great goal.

\section{REFERENCES}

1. ABRELL-VOGEL, C., AND ROWOLD, J. 2014. Leaders' commitment to change and their effectiveness in change - a multilevel investigation. J. Org. Change Manag. 27, 900-921. doi: 10.1108/jocm-07-2012-011.

2. AGARWAL, P. 2018. How to create a positive Workplace Culture. United Kingdom. Forbes.

3. ALEXANDER, C. 2012.Computational Statistics \& Data Analysis Volume 56, Issue 6, June 2012, Pages $1880-189$.

4. ALLEN, I. E., \& SEAMAN, J. 2017. Digital Learning Compass: Distance Education Enrollment Report 2017.

5. ALLEN GP, MOORE WM, MOSER LR, NEILL KK, SAMBAMOORTHI U, BELL HS. 2016.The Role of Servant Leadership and Transformational Leadership in Academic Pharmacy. Am J Pharm Educ. $2016 ; 80(7): 113$. doi:10.5688/ajpe807113.

6. ASBARI, M., DYLMOON, H.D., \& PURWANTO, A. 2021. Managing Employee Performance: From Leadership to Readiness for Change. International Journal of Social and Management Studies, 2(1), 74-85. https://doi.org/10.5555/ijosmas.v2i1.12

7. BAGWELL, A. 2019. Exploring the leadership practices of elementary school principals through a distributed leadership framework: a case study. California State University, Northridge. Retrieved from: https://files.eric.ed.gov/fulltext/EJ1206775.pdf

8. BERHSTOCK-SHERRATT, E., PAYNE G. 2020. Teacher leadership in uncertain times: recommendations boardcertified teachers for school, district, and state leaders. National Board for Professional Teaching Standards 
9. BOUСНСНАMМА, Y. 2012. Leadership Practices in Effective Schools in Disadvantaged Areas of Canada. EducationResearchInternational, vol. 2012, Article ID 712149, 16 pages, 2012. https://doi.org/10.1155/2012/712149

10. CARNEVALE, J. B., \& HATAK, I. 2020. Employee adjustment and well-being in the era of COVID-19: Implications for human resource management. Journal of business research, 116, $183-187$. https://doi.org/10.1016/j.jbusres.2020.05.037

11. CAULFIELD, M.J. 2015. Genetic risk, coronary heart disease events, and the clinical benefit of statin therapy: an analysis of primary and secondary prevention trials, The Lancet, Volume 385, Issue 9984,2015,Pages2264-2271.ISSN 0140-6736,https://doi.org/10.1016/S0140-6736(14)61730-X.

12. CHERRY, K. 2018. Leadership theories - 8 Major Leadership theories. Retrieved October 1, 2018 from http://www.psychology.about.com/od/leadership/p/leadtheories.htm.

13. CARLTON, MP. \& WINSLER, A. 1999. School Readiness: The Need for a Paradigm Shift, School Psychology Review, 28:3, 338-352, DOI: 10.1080/02796015.1999.12085969

Choi SL, Goh CF, Adam MB, Tan OK. 2016. Transformational leadership, empowerment, and job satisfaction: the mediating role of employee empowerment. Hum Resour Health. 2016;14(1):73. Published 2016 Dec 1. doi:10.1186/s12960-016-0171-2.

14. COHEN, J., McCABE, L., MICHELLI, N. M., et al. 2009. School Climate: research, policy, practice, and teacher education. Teachers College Record, 111(1), 180-213.

15. CHERKOWSKI, S. 2016. Exploring the role of the school principal in Cultivating a professional learning climate. Journal of School Leadership, 26(3), 523-543.

16. CRUICKSHANK, V. 2017. The Influence of School Leadership on Student Outcomes. Open Journal of Social sciences. 05. 115-123.10.4236/ jss. 2017.59009

17. DE PAEPE, L., ZHU, C., \& DEPRYCK, K. 2018. Online Dutch L2. learning in adult education: Educators' and providers' viewpoints on needs, advantages and disadvantages. Open Learning, 33(1), 18- 33. https://doi.org/10.1080/02680513.2017.1414586

18. DOBSS, R., DEL CARMEN, A., \& WAID-LINDBERG, C. 2017. Students' perceptions of online courses: The effect of online course experience. The Quarterly Review of Distance Education, 18(1), $98-109$ Retrieved from https://eric.ed.gov/?id=EJ864039.

19. EJIMABO, N.O. 2015. The Influence of Decision Making in Organizational Leadership and Management Activities. J Entrepren Organize Manage 4: 138. doi:10.4172/2169-026X.1000138

20. ELDOR, L. AND SHOSHANI, A. 2016. Caring relationships in school staff: Exploring the link between compassion and teacher work engagement June 2016Teaching and Teacher Education Volume 59(October 2):126136.http://www.sciencedirect.com/science/article/pii/S0742051X16 301135

21. FERNANDEZ, A.A. \& SHAW, J.P 2020. Academic Leadership in a Time of Crisis: The Coronavirus and COVID-19. Journal of Leadership studies. Phoenix University.

22. FRANCA, GLENFORD C. 2019. Conflict Resolution Skills and Team Building Competence of School Heads: A Model for Effective School Management. SPAMAST Research Journal, 7 (1), 39-43.

23. GARY,K. 2016. Neoliberal Education for Work Versus Liberal Educationf or Leisure, Studies in Philosophy and Education, 10.1007/s11217- 016-9545-0, 36, 1, (83-94).

24. GRAEN, G., ROWOLD, J., \& HEINITZ, K. 2010. Issues in operationalizing and comparing leadership constructs. Leadership Quarterly, 21 (3), 563-575.

25. GRAY, C., WILCOX, G., \& NORDSTOKKE, D. 2017. Teacher mental health, school climate, inclusive education and student learning: a review. Canadian Psychology/Psychologie Canadienne, 58(3), 203.

26. GRAYSO, J. L., \& ALVAREZ H. K. 2008. School climate factors relating to teacher burnout: a mediator model. Teaching and Teacher Education, 24(5), 1349-1363.

27. GONSER, S. 2020. Tips for Principals Shifting Their Schools to Distance Learning. Retrieved from: https://www.edutopia.org/article/tips- principals-shifting-their-schools-distance-learning

28. GRAUE, E. 2006. The Answer Is Readiness- Now What Is the Question?, Early Education and Development, 17:1, 4356, DOI: 10.1207/s15566935eed1701_3

29. GUNAWARDENA, C., McISAAC, M., \& JONASSEN, D. 2008. Distance education. In D. Jonassen (Ed.), Handbook of research on educational communications and technology: Project of the Association for Educational Communications and Technology (AECT series), (pp.355- 396). New York: Lawrence Erlbaum Associates Inc. Retrieved from https://ocw.metu.edu.tr/file.php/118/Week10/Gunawardedna-McIsaac-distance-ed-pdf.

30. HANSEN, K.M. 2016. Effective school leadership practices in schools with positive climates in the age of high-stakes teacher evaluations. All NMU Master's Theses. 125.

31. HARTFORD, S.C. 2000. Employ perceptions of leader credibility and its relationship to employee communication satisfaction and Health Care Organization. Doctoral dissertation, Southern Illinois University at Carbondale.

32. HARRISON,K. 2020. Why employee recognition is so important-and what you can do about it. Australia. Cutting-edge. 
33. HOLLANDER, E.P. 1986. On the central role of leadership process. International Review of Applied Psychology, 35, p. 39-52.

34. HORSPOOL, A., \& LANGE, C. 2012. Applying the scholarship of teaching and learning: Student perceptions, behaviours and success online and face-to-face. Assessment \& Evaluation in Higher Education, 17(1), 73-88 Retrieved from https://srhe.tandfonline.com/doi/abs/10.1080/02602938.2010.496532\#.XX-XPigzZPY.

35. HUGHES, W.H. \& PICKERAL, T. 2013. School climate and shared leadership.In Dary, T. \& Pickeral, T. (ed) (2013). School Climate Practices for Implementation and Sustainability. A School Climate Practice Brief, Number 1, New York, NY: National School Climate Center.

36. ISAACS, A.J. 2003. An Investigation of Attributes of School Principals in Relation to Resilience and Leadership Practices. Florida State University Libraries.

37. JACOBS C; PFAFF H; LEHNER B, ET AL. 2013.The Influence of Transformational Leadership on Employee WellBeing: Results From a Survey of Companies in the Information and Communication Technology Sector in Germany. J Occup Environ Med. 2013;55(7):772-8. doi:10.1097/JOM.0b013e3182972ee5

38. JOHNSON, K. 2017. Deaf Education in China: 2000 to 2020. University of Minnesota Publishers, Minnesota, USA.

39. JOYNES, C., ROSSIGNOLI, S., \& FENYIWA AMONOO-KUOFI, E. 2019. 21st Century Skills: Evidence of issues in definition, demand and delivery for development contexts (K4D Helpdesk Report). Brighton, UK: Institute of Development Studies.

40. KEEGAN, D. J. 1980. On the Nature of Distance Education. ZIFF Papiere Retrieved from https://eric.ed.gov/?q=Desmond + keegan\&id $=E D 311890$

41. KEEGAN, D. 1994. The competitive advantages of distance teaching universities. Open Learning: The Journal of Open, Distance and e-Learning, 9(2), 36-39.

42. KEEGAN, D. 2002. The future of learning: From eLearning to mLearning. Hagen: Zentrales Institut fur Fern Universitat Retrieved fromhttps://www.academia.edu/3442041/The_future_of_learning From_eLearning_to_mLearning

43. KILLAM, K. 2020. How to Prevent Loneliness in a Time of Social Distancing [online]

44. KOHLL, A 2018. How to build a positive culture. Omaha, Nebraska. Forbes.

45. KOUZES, J.M. \& POSNER, B.Z. 1987. The Leadership challenge: How to get extraordinary things done in organizations. San Francisco: Jossey - Bass Publishers.

46. KOUZES, J.M. \& POSNER, B.Z. 1995. The leadership challenge. How to keep getting extraordinary things done in organizations (2nd Ed.). Jossey-Bass publishers: San Francisco.

47. KOUZES, J.M. \& POSNER, B.Z. 2002. Leadership challenge (3rd Ed.). San Francisco:Jossey-Bass.

48. KOUZES, J.M. \& POSNER, B.Z. 1993. Leadership practices inventory. A self-assessment and analysis (expanded edition). San Francisco: Jossey - Bass Inc., Publishers.

49. LADD, G., HERALD, S. \& KOCHEL, K. 2006. School Readiness: Are There Social Prerequisites?, Early Education and Development, 17:1, 115-150,DOI: 10.1207/s15566935eed1701_6

50. LAPADA, ARIS. 2020. Teachers' Covid-19 Awareness, Distance Learning Education Experiences and Perceptions towards Institutional Readiness and Challenges. International Journal of Learning, Teaching and Educational Research. 19. 10.26803/ijlter.19.6.8.

51. LEHRER, J. 2018. "Psychopaths and Rational Morality," ScienceBlogs, April 29, 2010, accessed May 1, 2018, http://scienceblogs.com/cortex/2010/04/29/psychopaths-and-rational-moral/

52. LUO, Y.J.; LI, Y.P.; CHOI, J.N.; DU, J. 2020 Visionary leadership effectiveness: Moderating roles of power distance and middle-way thinking. Scientific Journal Publishers: Social Behavior and Personality: an international journal, Volume 48, Number 12, 2020, pp. 1-12(12)

53. MASHBURN, AJ., \& PIANTA, RC. 2006. Social Relationships and School Readiness, Early Education and Development, 17:1, 151-176, DOI: 10.1207/s15566935eed1701_7

54. MIRANDA, A.T. 2020. World's Distribution of COVID-19 Cases and The Benford's Law. Cape Comorin Journal 2 (V), 16-20.

55. MESSENGER, J.C. AND GSCHWIND, L. 2016. Three generations of Telework: New ICTs and the Revolution from Home Office to Virtual Office. New Technology, Work and Employment, 31: 195-208.

56. MOUR ÃO, L. 2018. The Role of Leadership in the Professional D Development of Subordinates, Leadership, Suleyman Davut Göker, IntechOpen, DOI: 10.5772/intechopen.76056. Available from: https://www.intechopen.com/books/leadership/the-role-of- leadership-in-the-professional-development-ofsubordinates

57. MORGAN, WILSON, L.N.W. 2015. The influence of school leadership practices on classroom management, school environment, and academic underperformance. Walden University. Retrieved from: https://scholarworks.waldenu.edu/cgi/viewcontent.cgi? article $=1451$ \&context $=$ dissertations

58. MUGAVIN, B. 2020. LEADERSHIP DEVELOPMENT: Encourage The Heart When Leading Virtually. 
59. NAKAMURA, M. 2017. The state of distance education in Japan. Quarterly Review of Distance Education, 18(3), 7587.

60. ORBÉ-AUSTIN, R. 2020. Own Your Greatness: Overcome Impostor y.Syndrome, Beat Self-Doubt, and Succeed in Life. Ulysses Press. New York City.

61. ROSEN, M. A., DIAZGRANADOS, D., DIETZ, A. S., BENISHEK, L. E., THOMPSON, D., PRONOVOST, P. J., \& WEAVER, S. J. 2018. Teamwork in healthcare: Key discoveries enabling safer, high-quality care. The American psychologist, 73(4), 433-450. https://doi.org/10.1037/amp0000298

62. SENEKAL, Q. 2020 Transformational Leadership: Enabling Others To Act: $\quad$ International Journal Of Business And Management Studies Vol 12, No 2, 2020 ISSN: 1309-8047 (Online).

63. SMIRCICH L., \& MORGAN, G. 1982. Leadership: The management of meaning. Journal of Applied Behavorial Sciences, 18, 3, p. 257-273.

64. SNOW, K. 2006. Measuring School Readiness: Conceptual and Practical Considerations, Early Education and Development, 17:1, 7-41, DOI: 10.1207/s15566935eed1701_2

65. TASSELLI S., KILDUFF M., LANDIS B. 2018.Personalitychange: Implications for organizational behavior. Academy of Management Annals. 2018;12(2):467-493.

66. THAPA, A., COHEN, J., GUFFEY, S., et al. 2013. A review of school climate research. Review of Educational Research, 83(3), 357-385.

67. THE LEADERSHIP CHALLENGE. 2011. Workshop and The Five Practices of Exemplary Leadership ${ }^{\circledR}$ are registered trademarks of John Wiley \& Sons, Inc. The associated icons are copyright (C) 2011 John Wiley \& Sons, Inc. www.leadershipchallenge.com.

68. UNITED NATIONS, 2020. Policy Brief: Education during COVID-19 and beyond. Retrieved from https;//www.un.orgdevelopment/ 19_and_education_august_2020.pdf

69. VUGT, M.V. ROBERT HOGAN, AND ROBERT B. KAISER, 2018. "Leadership, Followership, and Evolution: Some Lessons from the Past," American Psychologist 63, no. 3 (April 2008): 182-96, accessed May 1, 2018, http://www.professormarkvanvugt.com/images/files/LeadershipFollowershipandEvolution-AmericanPsychologist2008.pdf. 